\title{
EURASIAN JOURNAL OF ECONOMICS AND FINANCE
}

\section{www.eurasianpublications.com}

\section{THE INTERACTION EFFECT OF TASK - TECHNOLOGY FIT AND JOB Satisfaction on Job Performance in ERP Context: Case Study OF VIETNAMESE ENTERPRISES}

\author{
Pham Quang Huy \\ Corresponding Author: University of Economics Ho Chi Minh City, Vietnam \\ Email: pquanghuy@ueh.edu.vn \\ Vo Van Nhi \\ University of Economics Ho Chi Minh City, Vietnam \\ Email: nhi_vo1958@yahoo.com \\ Pham Tra Lam \\ University of Economics Ho Chi Minh City, Vietnam \\ Email: phamtralamais@ueh.edu.vn
}

\begin{abstract}
Job performance and technology in work have been researched with a number of global issues. The effect may have different levels in countries with the rapidly development in technology. It is important to know the impact with moderator value of job satisfaction to this relationship conducted by many previous papers. The main aim of this study was to examine the role of job satisfaction in the relationship between individual job performance and task - technology fit in Enterprise Resource Planning (ERP) environment. The study was test and examined by 225 individuals in the Vietnamese enterprises. The results of the study provided additional bases for assessing the success of ERP system to researchers, businesses, and suppliers. In addition, final figures of the PLS analysis revealed that task - technology fit was significantly and positively related to job satisfaction and individual job performance in ERP environment. Furthermore, job satisfaction had an effect on individual job performance in ERP context.
\end{abstract}

Keywords: Enterprise Resource Planning, Job Performance, Job Satisfaction, Task Technology Fit

JEL Classifications: M15, O15, O3

\section{Introduction}

Companies all over the world have adopted Enterprise Resource Planning (ERP) systems to integrate their business processes and stay competitive (Wei and Wang, 2004). Because ERP is information system (IS), user perceptions about an ERP system play an important role in both usage and success of ERP (Delone and Mclean, 2003). Some organizations have applied the ERP system but users are non-adoption of the system (Plaza and Rohlf, 2008). In this case, job performance and job satisfaction are lower and turnover rates are higher (Sykes et al. 2014). In 
addition, if the job performance of individual is low, it will adversely affect the performance of organization (Kositanurit et al. 2006). As a critical indicator of ERP implementation success, it is important to examine possible factors that affect employee job performance (Sykes et al. 2014).

Bradford and Florin (2003) developed and tested a model of ERP implementation success which is measured by perceived organizational performance and user satisfaction. While the study of Bradford and Florin (2003) examined perceived organizational performance, the others explored the factors that can impact individual performance when using ERP systems such as Kositanurit et al. (2006), Park et al. (2007), Sykes et al. (2014), Sykes (2015). Kositanurit et al. (2006) provided evidence that system quality, utilization, and ease of use are the three important factors bearing on individual performance in ERP environment.

The study of Park et al. (2007) found that the users' ability to understand ERP knowledge influenced its performance and organizational support moderated the relationship between their absorptive capacity and performance. Sykes et al. (2014) show workflow advice and software advice are associated with job performance. Besides, that study found that the interactions of workflow and software get-advice, workflow and software give-advice, and software get- and give-advice impacted job performance. Similarly, Sykes (2015) disclosed both traditional support structures and peer advice ties were found to influence the various outcomes including system satisfaction, job stress, job satisfaction and job performance. On the individual level, the factors that are proven to have an impact on the job performance in ERP environment include system quality, utilization, and ease of use, users' ability to understand ERP knowledge, workflow advice, software advice, traditional support structures and peer advice ties. Similar to the above studies, this work seeks to examine post - implementation employee job performance.

Based on these above content, this paper is structured as follows. First, the article describes the theoretical background on individual job performance, job satisfaction and task technology fit. Next, it presents the research methodology used. Then, the paper also demonstrates the key findings of research. Finally, it offers various conclusions and further work.

\section{Literature Review and Background Theory 2.1. Individual Job Performance}

Job performance relates to the accomplishment of a portfolio of tasks by an individual (Goodhue and Thompson, 1995). According to TTF theory, performance benefits improve a range of performance outcomes (Furneaux, 2012). The specific outcomes that have been examined in prior TTF research have included system use/intention to use, job performance, satisfaction with technology, opinions regarding a technology, appropriation changes made, decision efficiency, decision quality, decision strategy employed, joint profit attained, number of ideas generated, quality of solution, task completion time, task accuracy, ability to perform tasks, perceived ease of use, perceived usefulness, perceived playfulness, perceived risk, and so on (Furneaux, 2012).

High performance implies that there is a mix between improved efficiency, improved effective and/ or improved quality (Goodhue and Thompson, 1995). It was often confused with productivity (Ruppel and Harrington, 1995). However, it is actually measured by more global variables such as the quality of outputs, job knowledge, leadership, or judgment (Ruppel and Harrington, 1995). In the traditional office, job performance is largely established by scanning for employees' presence and through direct and indirect observations (Ruppel and Harrington, 1995).

There exists a wide range of employee outcomes in ERP implementation, such as systems satisfaction, job stress, job satisfaction, and individual job performance (Sykes, 2015). Job performance is a way to measure employee outcomes. Job performance is a good way of performing an employee's work (Sykes, 2015). This study defined individual job performance in ERP environment was that the employee feels that with the help of ERP systems, he/she can improve a range of performance outcomes. 
Huy et al. / Eurasian Journal of Economics and Finance, 7(1), 2019, 48-61

\subsection{Job Satisfaction}

Job satisfaction is a function of "the extent to which rewards actually received meet the perceived equitable level of rewards" (Porter and Lawler 1968, p. 31). Job satisfaction is somehow combined to determine overall job satisfaction (Jiang et al. 2012). Previous studies disclosed that an increase in the user satisfaction of information systems would lead to positive emotions, attitudes, intentions, and behavior (Michalos, 1985). According to Jiang et al. (2012), achieving a satisfaction at individual level has become major objective of professional information systems. In addition, satisfaction is a concept that is frequently studied when evaluating a product, service, practice, or condition (Davis, 1989). The use of satisfaction to measure success is also consistent with theories such as theory of reasoned action - TRA (Ajzen and Fishbein, 1969), theory of planned behavior (TPB) (Aijen, 1991), information systems success model (Delone and Mclean, 1992; DeLone and McLean, 2003). In addition, if a member of information systems is his/ her satisfaction, it will lead to less the intention to leave the organization (Ferratt et al. 2005). As a result, satisfaction is used to explain and predict various aspects of information systems and behavior of stakeholders (Jiang et al. 2012). At present, many studies have evaluated the information systems success in general and ERP system in particular by measuring user satisfaction (Kanellou and Spathis, 2013). According to discrepancy theory, the user satisfaction is divided into two categories related to information systems including user satisfaction with information systems and individual satisfaction related to information systems job (Jiang et al. 2012). While studies on user satisfaction with information systems have been relatively well conducted, paper has not found many studies on individual satisfaction related to information systems job. In particular, we find only a small number of studies that have studied the job satisfaction of ERP users including Morris and Venkatesh (2010), Sykes et al. (2014) and Sykes (2015). According to Sykes et al. (2014), job satisfaction affects employee's job performance in an ERP environment. In this study, the effect of job satisfaction to individual job performance in ERP context was also examined. Job satisfaction in this context is understood to be a combination of different aspects of work from using an ERP that makes employee satisfied with ERP systems.

\subsection{Task - Technology Fit}

Task - technology fit concept derives from the Task-Technology Fit theory (TTF) (Goodhue, 1995; Goodhue and Thompson, 1995; Zigurs and Bucklva, 1998). According to TTF, the task technology fit represents the degree of matching or alignment between the capabilities of an information system and the demands of the tasks that must be performed (Furneaux, 2012). Goodhue and Thompson (1995) proved that task - technology fit has an effect on the performance impacts including job performance, satisfaction, perceived usefulness, utilization, ease of use, perceived risk, and so on (Furneaux, 2012). To the best of our knowledge, there are few studies on tasks - technology fit in ERP context. Only research by Kositanurit et al. (2006) investigated the impact of task-technology fit on job performance in ERP environment. Similar to Kositanurit et al. (2006), this study examined the impact of task-technology fit on individual job performance in ERP environment. This study defined task - technology fit is the degree of relevance between the ability of ERP system and the tasks which an employee must perform.

\section{Research Method and Research Model 3.1. Research Model and Hypotheses}

Based on three theories including TTF, TAM and TTF models combined, and the DeLone and McLean (2013) IS Success Model, this study develops the hypothesis $\mathrm{H}_{1}$. Firstly, according to TTF, task - technology fit impact on performance benefit (Goodhue and Thompson, 1995) while individual job performance is used as an indicator of performance benefit (Furneaux, 2012). Secondly, TAM and TTF models combined show that task - technology fit have significant effect on actual tool use (Dishaw et al. 2012). At the same time, the user behavior has an impact on 
the job performance (Rajan and Baral, 2015). Finally, Petter et al. (2013) suggested that task compatibility impact on the IS success. Task compatibility is the fit or consistency between the task and the IS that supports that task (Petter et al. 2013). In this study, task - technology fit was defined similarly to task compatibility. Petter et al. (2013) measured the IS success based on the update DeLone and McLean (2003) IS success model, including information quality, system quality, service quality, intention to use/ use, user satisfaction, and net benefits. In this study, individual job performance was considered an indicator of net benefits. Based on the above arguments, this study developed hypothesis $\mathrm{H}_{1}$.

This hypothesis is also supported by several studies, such as Norzaidi et al. (2009), Teo and Bing (2008), Kositanurit et al. (2006), D'Ambra and Wilson (2004a), D'Ambra and Wilson (2004b), Belanger et al. (2001), Wongpinunwatana et al. (2000), Goodhue et al. (1997), Goodhue and Thompson (1995), Goodhue (1995). In particular, Staples and Seddon (2004) show that task - technology fit had an impact on individual job performance in both kinds of IT use, voluntary and mandatory as well. In the study, if an enterprise is being used an ERP system, employees are required to use it. So, Staples and Seddon (2004) strongly support to the hypothesis $\mathrm{H}_{1}$. in ERP environment.

$H_{1}$ : The task - technology fit has a positive effect on the job performance of employee

Beside the DeLone and McLean (2013) IS Success Model and ECM, the study of Sykes et al. (2014) demonstrates that job satisfaction affects employee's job performance in an ERP environment. Based on these backgrounds, this study proposes the $\mathrm{H}_{2}$ hypothesis. Additionally, supporting $\mathrm{H}_{2}$, many studies in the field of psychology find individual job satisfaction influencing job performance (Judge et al. 2001). According to Igbaria and Tan (1997), the job satisfaction of IS users has a strong impact on their job performance. Etezadi-Amoli and Farhoom (1996) and Bradford and Florin (2003) also showed similar results. environment.

$\mathrm{H}_{2}$ : Job satisfaction has a positive effect on the job performance of employee in ERP Based on the findings from TTF and Belanger et al. (2001), the $\mathrm{H}_{3}$ hypothesis was developed: ERP environment.

$H_{3}$ : The task - technology fit has a positive effect on the job satisfaction of employee in

Figure 1 represents the proposed research model that was used for this research.

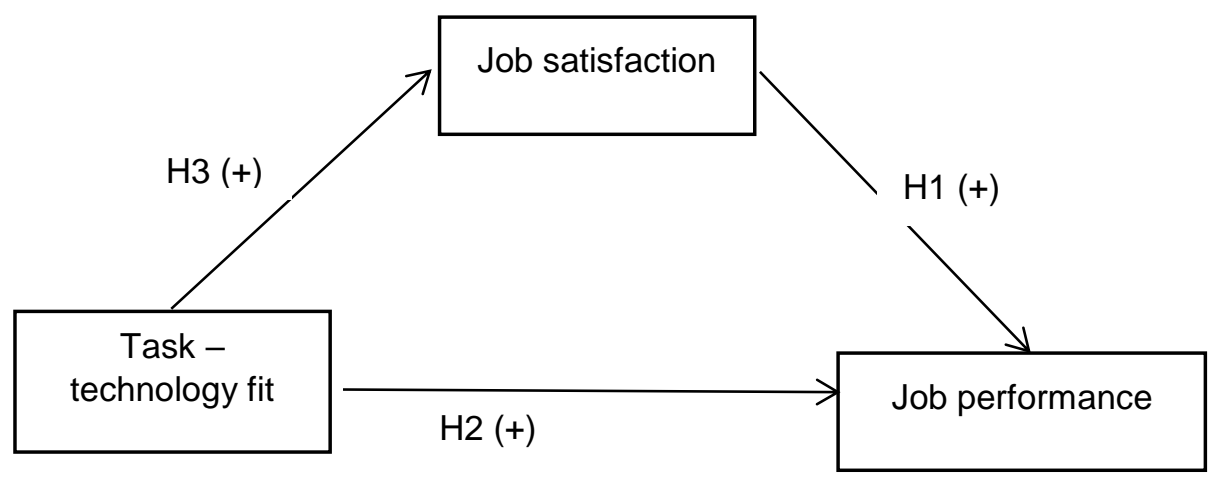

Figure 1. Proposed research model 


\subsection{Research Methodology}

All research constructs included in this study had multi-item scales derived from the relevant literature. Each item in the survey employed a 7-point Likert scale $(1=$ strongly disagree, $7=$ strongly agree), and a not applicable (NA) option was available for the respondents to choose. The paper now elaborates its measures for the constructs.

This study accepted scale of the individual job performance in ERP environment (PER) from Goodhue and Thompson (1995). PER is a first - order construct and reflective measures with 2 items. Paper measured task - technology fit (TTF) using a 11- item scale adapted from Kositanurit et al. (2006) that captures the eight dimensions including currency (CURR), right data (RDAT), right level of detail (RDET), meaning (MEAN), ease of use (EOU), training (TRAI), authorization (AUT) and system reliability (REL). TTF is a high - order construct and reflective reflective measures. The job satisfaction (JOBSA) was measured with 7 items adapted from Sykes et al. (2014). JOBSA is a first - order construct and reflective measures.

\subsection{Data Collection}

This study was conducted using quantitative means as it aimed to validate the proposed relationships between factors affecting individual job performance in ERP context. The research instrument was used a questionnaire distributed to the end-users (employees). The data were collected from June 2017 to August 2017. The questionnaires were sent by email or postal mail to an initial sample of 500 employees who are using ERP system. This research collected 265 responses (response rate was 53\%). Baruch and Holtom (2008) point out that for surveys addressed to individual, the average response rate is $52.7 \%$. Thus, the response rate of our study seems to be above average. Of the 265 employees, 225 employees from 49 companies gave usable responses at all points of measurement. Hence, a number of final responders put into this research is 225 staffs.

Table 1 presents the sample characteristics age, gender, education and average computer experience. The sample consisted of $161(71.6 \%)$ female and $64(28.4 \%)$ male. Table 1 also shows that $75.5 \%$ of the sampled individuals were fewer than 35 . In addition, $72 \%$ of the sampled individuals had bachelor degree. Average experience using an ERP system was 2.56 years.

Table 1. Sample characteristics $(n=225)$

\begin{tabular}{|c|c|c|c|c|c|}
\hline Category & Frequency & $\begin{array}{c}\text { Percentages } \\
(\%)\end{array}$ & Category & Frequency & $\begin{array}{c}\text { Percentages } \\
(\%)\end{array}$ \\
\hline Age & & & Education & & \\
\hline$<35$ & 170 & 75.5 & Master & 7 & 3.1 \\
\hline $35-45$ & 47 & 20.9 & Bachelor & 162 & 72 \\
\hline$>45$ & 8 & 3.6 & Colleges & 43 & 19.1 \\
\hline Gender & & & Others & 13 & 5.8 \\
\hline Male & 64 & 28.4 & Average computer & \multirow{2}{*}{\multicolumn{2}{|c|}{2.56}} \\
\hline Female & 161 & 71.6 & experience (years) & & \\
\hline
\end{tabular}

Because there was only one respondent for each individual, common method bias (CMB) was a potential problem. In this study, this article took a number of steps suggested by Podsakoff et al. (2003) to reduce the possibility of common method bias. Firstly, paper used multiple items for each construct and ensured the neutral wording of the items. Secondly, paper assured respondents of the anonymity of their responses and emphasized that there were no right or wrong answers; each of these actions enabled them to answer questions as honestly as possible. Thirdly, we separated the measurement of predictors and criterion variables in the questionnaire to diminish the respondent's ability and motivation to use his/her prior responses to answer subsequent questions. Finally, we also used the Harman's single-factor test and the marker variable approach to control for Common Method Variance (CMV). Results are discussed in data analysis and results section. 


\section{Data analysis and results 4.1. Measurement model}

This article estimated the internal consistency reliability, convergent validity, and discriminant validity of each measurement scale to assess the measurement model. Its research used two criterions for internal consistencies were composite reliability (CR) and Cronbach's alpha. All the reflective constructs in our model shown in Table 2 have a Cronbach's alpha over the cut off of 0.70 , as suggested by Hair et al. (2016). Similarly, a composite reliability (CR) of all the constructs is also higher than 0.7 , as suggested by Fornell and Larcker (1981), implying high internal consistency.

Table 2. Results summary of measurement models

\begin{tabular}{|c|c|c|c|c|c|c|c|}
\hline \multirow{3}{*}{$\begin{array}{l}\text { Latent } \\
\text { variable }\end{array}$} & \multirow{3}{*}{ Indicators } & \multicolumn{3}{|c|}{ Convergent validity } & \multicolumn{2}{|c|}{$\begin{array}{c}\text { Internal consistency } \\
\text { reliability }\end{array}$} & \multirow{3}{*}{$\begin{array}{l}\text { Discriminant } \\
\text { validity }\end{array}$} \\
\hline & & Loadings & $\begin{array}{l}\text { Indicator } \\
\text { reliability }\end{array}$ & AVE & $\begin{array}{l}\text { Composite } \\
\text { reliability }\end{array}$ & $\begin{array}{l}\text { Cronbach's } \\
\text { Alpha }\end{array}$ & \\
\hline & & $>0.7$ & $>0.5$ & $>0.5$ & $0.6-0.95$ & $0.6-0.95$ & \\
\hline \multirow{2}{*}{ PER } & $\begin{array}{l}\text { PER1: ERP systems system } \\
\text { has a positive impact on my } \\
\text { productivity in my job }\end{array}$ & $0.966^{* * *}$ & 0.933 & \multirow{2}{*}{0.937} & \multirow{2}{*}{0.932} & \multirow{2}{*}{0.967} & \multirow{2}{*}{ Yes } \\
\hline & $\begin{array}{l}\text { PER2: ERP systems is an } \\
\text { important aid to me in the } \\
\text { performance of my job }\end{array}$ & $0.970^{* * *}$ & 0.941 & & & & \\
\hline \multirow{7}{*}{ JOBSA } & $\begin{array}{l}\text { JOBSA1: All in all, how } \\
\text { satisfied are you with the } \\
\text { persons in your work group }\end{array}$ & $0.745^{\star * *}$ & 0.554 & \multirow{7}{*}{0.608} & \multirow{7}{*}{0.892} & \multirow{7}{*}{0.916} & \multirow{7}{*}{ Yes } \\
\hline & $\begin{array}{l}\text { JOBSA2: All in all, how } \\
\text { satisfied are you with your } \\
\text { supervisor }\end{array}$ & $0.809^{\star * *}$ & 0.654 & & & & \\
\hline & $\begin{array}{l}\text { JOBSA3: All in all, how } \\
\text { satisfied are you with your job }\end{array}$ & $0.761^{\star * *}$ & 0.578 & & & & \\
\hline & $\begin{array}{l}\text { JOBSA4: All in all, how } \\
\text { satisfied are you with this } \\
\text { organization, compared to } \\
\text { most }\end{array}$ & $0.787^{\star * *}$ & 0.620 & & & & \\
\hline & $\begin{array}{l}\text { JOBSA5: Considering your } \\
\text { skills and the effort you put into } \\
\text { your work, how satisfied are } \\
\text { you with your pay }\end{array}$ & $0.748^{* * *}$ & 0.560 & & & & \\
\hline & $\begin{array}{l}\text { JOBSA6: How satisfied do you } \\
\text { feel with the progress you have } \\
\text { made in this organization up to } \\
\text { now }\end{array}$ & $0.808^{* * *}$ & 0.653 & & & & \\
\hline & $\begin{array}{l}\text { JOBSA7: How satisfied do you } \\
\text { feel with your chance for } \\
\text { getting ahead in this } \\
\text { organization in the future }\end{array}$ & $0.798^{\star * *}$ & 0.637 & & & & \\
\hline CURR & $\begin{array}{l}\text { CURR: The data provided by } \\
\text { ERP systems is up-to-date } \\
\text { enough for my purposes }\end{array}$ & 1.000 & 1.000 & 1.000 & 1.000 & 1.000 & Yes \\
\hline RDAT & $\begin{array}{l}\text { RDAT: ERP systems available } \\
\text { to me is missing critical data } \\
\text { that are very useful to me in } \\
\text { my job }\end{array}$ & 1.000 & 1.000 & 1.000 & 1.000 & 1.000 & Yes \\
\hline RDET & $\begin{array}{l}\text { RDET: ERP systems maintain } \\
\text { data at an appropriate level of } \\
\text { detail for my group's tasks }\end{array}$ & 1.000 & 1.000 & 1.000 & 1.000 & 1.000 & Yes \\
\hline MEAN & $\begin{array}{l}\text { MEAN: The exact definition of } \\
\text { data fields relating to my tasks } \\
\text { is easy to find out }\end{array}$ & 1.000 & 1.000 & 1.000 & 1.000 & 1.000 & Yes \\
\hline \multirow{2}{*}{ EOU } & $\begin{array}{l}\text { EOU1: It is easy to learn how } \\
\text { to use ERP systems }\end{array}$ & $0.953^{\star \star \star}$ & 0.908 & \multirow{2}{*}{0.912} & \multirow{2}{*}{0.904} & \multirow{2}{*}{0.954} & \multirow{2}{*}{ Yes } \\
\hline & $\begin{array}{l}\text { EOU2: ERP systems I use is } \\
\text { convenient and easy to use }\end{array}$ & $0.957^{\star \star \star}$ & 0.916 & & & & \\
\hline
\end{tabular}

Note: ${ }^{\star \star \star} p<0.001$. 
Convergent validity is verified through the t-statistic for each factor loading. In PLS_SEM, this paper could use an indicator's outer loading. An outer loading should be above 0.7 and the t-statistic for each outer loading significant (Hair et al. 2016). Results of measurement models show that the items including AUT1, AUT2, REL1, REL2 and TRAI have outer loading above 0.7 but the t-statistic for each outer loading was not significant. As such, the AUT1, AUT2, REL1, REL2 and TRAI were excluded from the TTF scales. Table 2 shows the results of final measurement models. All factor loadings are greater than the typical cut off value of 0.7 (Hair et al. 2016) and significant at the $p<0.001$ level. In this study, we also used the average variance extracted (AVE) to assess convergent validity. An AVE value of 0.50 or higher indicates that, on average, the construct explains more than half of the variance of its indicators.

To establish discriminant validity, we used the HTMT criterion, Fornell - Larcker criterion and cross loadings. The results of discriminant validity are shown in Table 3. Crossfactor loadings are reported in Appendix.

Table 3. Results of discriminant validity

\begin{tabular}{cccccccccc}
\hline & Mean & SD & CURR & EOU & MEAN & PER & JOBSA & RDAT & RDET \\
\hline CURR & 4.50 & 1.530 & 1.000 & & & & & & \\
& & & & & & & & & \\
EOU & 4.428 & 1.383 & 0.390 & 0.955 & & & & & \\
& & & 0.410 & & & & & & \\
MEAN & 4.62 & \multirow{2}{*}{1.346} & 0.387 & 0.535 & 1.000 & & & & \\
& & & 0.387 & 0.562 & & & & & \\
PER & 5.029 & 1.327 & 0.351 & 0.716 & 0.634 & 0.968 & & & \\
& & & 0.362 & 0.779 & 0.657 & & & & \\
JOBSA & 4.846 & 0.977 & 0.317 & 0.543 & 0.407 & 0.528 & 0.780 & & \\
& & & 0.336 & 0.601 & 0.430 & 0.573 & & & \\
RDAT & 3.96 & \multirow{2}{*}{1.565} & 0.143 & 0.301 & 0.147 & 0.110 & 0.168 & 1.000 & \\
& & & 0.143 & 0.317 & 0.147 & 0.114 & 0.177 & & \\
RDET & 4.69 & \multirow{2}{*}{1.338} & 0.618 & 0.375 & 0.519 & 0.492 & 0.374 & 0.125 & 1.000 \\
& & & 0.618 & 0.394 & 0.519 & 0.508 & 0.394 & 0.125 & \\
\hline
\end{tabular}

Note: Number of the top rows: Fornell - Larcker criterion. Number of the below rows: HTMT criterion.

The square root of the AVE of each construct should be higher than its highest correlation with any other construct (Fornell and Larcker, 1981). Table 3 shows that the square root of AVE exceeds the correlation between other constructs. In addition, all HTMT of constructs are significantly smaller than 1 (Henseler et al. 2015). These results imply satisfactory discriminant validity.

\subsection{Structural model}

The structural model was examined to test the hypotheses. The $\mathrm{R}^{2}$, which is generated for each regression equation, indicates the explanatory power or variance explained of the latent endogenous variable. Figure 2 shows the structural model result. 


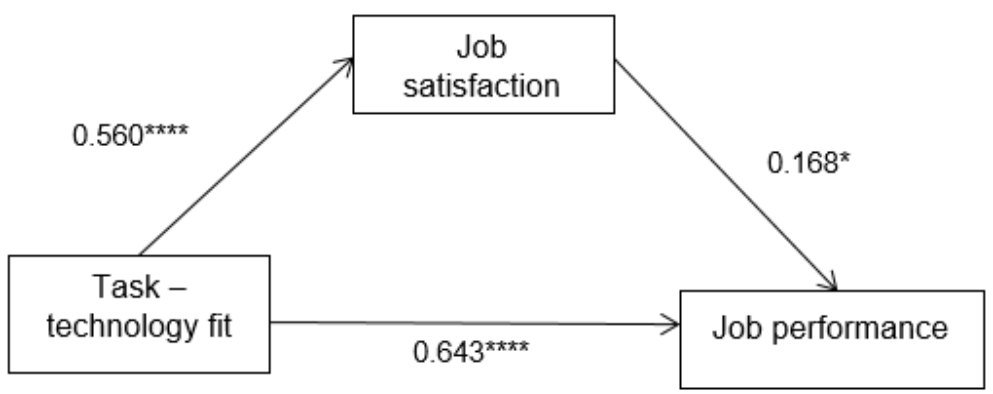

Figure 2. Result of proposed research model

Note: ${ }^{* *} p<0.001 . ;{ }^{*} p<0.05$

The PLS path analysis results show that task - technology fit was significantly related to individual job performance $(\beta=0.643, p<0.001)$ and job satisfaction $(\beta=0.560, p<0.001)$ supporting hypotheses $\mathrm{H}_{1}$ and $\mathrm{H}_{2}$. Job satisfaction was significantly related to individual job performance $(\beta=0.168, p<0.05)$ supporting hypotheses $\mathrm{H}_{3}$. The external variables including task - technology fit and job satisfaction could explain 56.2 percent variance in individual job performance $\left(R^{2}=0.562\right)$. Task - technology fit explained 31.4 percent of variance of job satisfaction $\left(R^{2}=0.314\right)$.

Next, it assessed the predictive relevance of the path model by $\mathrm{Q}^{2}$ values. All $\mathrm{Q}^{2}$ values are considerably above zero $\left(\mathrm{Q}^{2}\right.$ of individual job performance is 0.499 and $\mathrm{Q}^{2}$ of job satisfaction is 0.175$)$, thus providing support for the model's predictive relevance regarding the endogenous latent variables.

The final assessments address the $f^{2}$ effect sizes. Table 4 summarizes the results of the $\mathrm{f}^{2}$ effect sizes with respect to all the relationships in the model. Target constructs appear in the first row, whereas the predecessor constructs are in the first column. Table 4 shows TTF has a large effect size of 0.647 on PER and of 0.458 on JOBSA. However, JOBSA has a small effect size of 0.044 on PER.

Table 4. $f^{2}$ and $q^{2}$ effect sizes

\begin{tabular}{lcc}
\hline & \multicolumn{2}{c}{$\mathbf{f}^{2}$ effect sizes } \\
\hline & PER & JOBSA \\
TTF & 0.647 & 0.458 \\
JOBSA & 0.044 & \\
\hline
\end{tabular}

Additionally the variance inflation factor (VIF) was assessed to check multicollinearity. The collinearity diagnostics given in Table 5 shows that VIF for the independent variables higher than 0.20 (lower than 5) which further suggests that multicollinearity does not exist among the independent variables.

Table 5. Collinearity statistic

\begin{tabular}{lc}
\hline Construct & VIF \\
\hline Task - technology fit (TTF) & 1.458 \\
Job satisfaction (JOBSA) & 1.458 \\
\hline
\end{tabular}

\subsection{Mediation analysis}

In this study, we examined a mediator variable, intervenes between two other related constructs. Specifically, it also examined the role of job satisfaction in the relationship from task - technology fit to individual job performance in ERP context. Table 6 shows result of mediator variable. Research finds that both direct effect and indirect effect are significant. Our finding 
provided empirical support for the mediating role of job satisfaction in the relationship from task - technology fit to individual job performance in ERP context. Because path coefficient of the relationship from task - technology fit to individual job performance was 0.643 and significant, path coefficient of the relationship from task - technology fit to job satisfaction was 0.560 and significant, and path coefficient of the relationship from job satisfaction to individual job performance was 0.168 and significant, job satisfaction represents complementary mediation of the relationship from task - technology fit to individual job performance in ERP context.

Table 6. Significance analysis of the direct and indirect effects

\begin{tabular}{|l|c|c|c|c|c|c|c|c|}
\hline & $\begin{array}{c}\text { Direct } \\
\text { effect }\end{array}$ & $\begin{array}{c}95 \% \\
\text { confidence } \\
\text { interval of the } \\
\text { direct effect }\end{array}$ & $t$ value & $\begin{array}{c}\text { Significance } \\
(\mathrm{p}<0.05) ?\end{array}$ & $\begin{array}{c}\text { Indirect } \\
\text { effect }\end{array}$ & $\begin{array}{c}95 \% \\
\text { confidence } \\
\text { interval of the } \\
\text { indirect effect }\end{array}$ & $\begin{array}{c}t \\
\text { value }\end{array}$ & $\begin{array}{c}\text { Significance } \\
(\mathrm{p}<0.05) ?\end{array}$ \\
\hline $\begin{array}{l}\text { TTF }-> \\
\text { PER }\end{array}$ & 0.643 & {$[0.519 ; 0.757]$} & 10.558 & Yes & 0.094 & {$[0.017 ; 0.178]$} & 2.283 & Yes \\
\hline
\end{tabular}

\subsection{The Issue of Common Method Bias}

This research used the Harman's single-factor test and the marker variable approach to control for CMV in PLS analysis. Result of Harman's single-factor test by EFA shows that one factor only accounts for $45.294 \%$ of the total variance. In this case, CMV is not a serious problem (Podsakoff and Organ, 1986).

The marker variable approach was conducted by using marker variable. The first stage, we involved survey questionnaire that had a question as "Do you really like black coffee?" - this question was a marker variable (Lindell and Whitney, 2001). The next stage, this paper used PLS to test path coefficient of the relationship from marker variable to other variable in proposal model including job satisfaction, task - technology fit and individual job performance. Analysis results showed that all path coefficients of the relationships from marker variable to job satisfaction, task - technology fit and individual job performance were less than $0.3(-0.020$, 0.097 and -0.110$)$. This finding suggests that CMV was not a serious problem in this study. Besides, we also based on VIF to test CMB (Kock, 2015). Table 5 shows that all VIFs resulting from a full collinearity test were lower than 3.3 , the model can be considered free of CMB.

\section{Conclusion}

The results of this research supported most of the proposed relationships in the structural model. Most were consistent with the previous study results. Job satisfaction was significantly and positively related to individual job performance in ERP context $\left(\mathrm{H}_{1}\right.$ is supported). Task technology fit was significantly and positively related to job satisfaction and individual job performance in ERP environment $\left(\mathrm{H}_{2}\right.$ and $\mathrm{H}_{3}$ are supported). This study also shows that job satisfaction is a complementary mediation variable in relationship between task - technology fit and individual job performance in ERP context.

In ERP context, Kositanurit et al. (2006) found that task - technology fit was the important factor bearing on individual performance. Besides, the study of Sykes et al. (2014) demonstrated that job satisfaction affects employee's job performance in ERP environment. However, the impact of job satisfaction on employee's job performance is not strong (Sykes et al. 2014). The result of this study is similar to the result of Kositanurit et al. (2006) and Sykes et al. (2014). We found that both task - technology fit and job satisfaction effected on employee's job performance in ERP environment but task - technology fit factor was more important than job satisfaction factor.

This research also proved that task - technology fit has a positive effect on the job satisfaction of employee in ERP environment. According to Belanger et al. (2001), task technology fit had an impact on the job satisfaction in telecommuting. This result fits Belanger et al. (2001) but in ERP context. This study added to the empirical evidence in the application of background theories including TTF, TAM and TTF models combined, DeLone and McLean IS Success Model, and ECM. Besides, the results of this study also added to the theoretical 
background of ERP's success, namely, the individual job performance of employee in ERP context. Specifically, factors including job satisfaction and task - technology fit have a significant impact on the individual job performance of employee in ERP context. Furthermore, the results of this study help companies who are planning to use ERP systems and the ERP vendors and implementers become more knowledgeable about ERP's success and forecast success when using ERP systems.

In this study, the ERP success was measured by job performance of employees. The factors that have been tested are the impact on the individual job performance of employee in ERP context including job satisfaction and task - technology fit. Based on these results, the enterprises could plan the application to improve the efficiency of ERP systems. At the same time, the ERP vendors and developers could better advise and support their customers when delivering and deploying ERP systems.

This study has a few limitations. ERP implementations are complex and take time to complete (Markus and Tanis, 2000; Volkoff et al. 2007). However, this study was restricted to the shakedown phase of the implementation, which is widely acknowledged to be the most critical in terms of continuation or abandonment of ERP (Morris and Venkatesh, 2010). It could be that these findings might change over time, with some support structures gaining or losing influence on the outcomes of interest. Work that gives greater consideration to time would enrich our understanding of this phenomenon. Thus, an area for possible future work would be to examine ERP implementations and support structures over a significantly longer period of time-that is, across all phases of an implementation. This study chose an approach for the employee to assess his or her job performance in ERP context that is not evaluated by the supervisor of the employee. Future research should collect data through supervisors to measure the job performance of employee in ERP context.

\section{References}

Ajzen, I., 1991. The theory of planned behavior. Organizational Behavior and Human Decision Processes, 50(2), pp. 179-211. https://doi.org/10.1016/0749-5978(91)90020-T

Ajzen, I., and Fishbein, M., 1969. The prediction of behavioral intentions in a choice situation. Journal of experimental social psychology, 5(4), pp. 400-416. https://doi.org/10.1016/0022-1031(69)90033-X

Baruch, Y., and Holtom, B. C., 2008. Survey response rate levels and trends in organizational research. Human Relations, 61(8), pp. 1139 - 1160. https://doi.org/10.1177/0018726708094863

Belanger, F., Collins, R. W., and Cheney, P. H., 2001. Technology requirements and work group communication for telecommuters. Information Systems Research, 12(2), pp. 155-176. https://doi.org/10.1287/isre.12.2.155.9695

Bradford, M. and Florin, J., 2003. Examining the role of innovation diffusion factors on the implementation success of enterprise resource planning systems. International Journal of Accounting Information Systems, 4, pp. 205 - 225 https://doi.org/10.1016/S14670895(03)00026-5

Davis, F. D., 1989. Perceived usefulness, perceived ease of use, and user acceptance of information technology. MIS Quarterly, pp. 319-340. https://doi.org/10.2307/249008

D'Ambra, J., and Wilson, C. S., 2004a. Use of the world wide web for international travel: Integrating the construct of uncertainty in information seeking and the task-technology fit (TTF) model. Journal of the Association for Information Science and Technology, 55(8), pp. 731-742. https://doi.org/10.1002/asi.20017

D'Ambra, J., and Wilson, C. S., 2004b. Explaining perceived performance of the world wide web: Uncertainty and the task-technology fit model. Internet Research, 14(4), pp. 294310. https://doi.org/10.1108/10662240410555315

DeLone, W. H., and McLean, E. R., 1992. Information system success: The quest for the dependent variable. Information Systems Research, 3(1), pp. 60-95. https://doi.org/10.1287/isre.3.1.60 
Huy et al. / Eurasian Journal of Economics and Finance, 7(1), 2019, 48-61

DeLone, W. H., and McLean E. R., 2003. The DeLone and McLean model of information system success: A ten-year update. Journal of Managment Information Systems, 19(4), pp. 930. https://doi.org/10.1080/07421222.2003.11045748

Dishaw, L. J., Haire, R. N., and Litman, G. W., 2012. The amphioxus genome provides unique insight into the evolution of immunity. Briefings in functional genomics, 11(2), pp. 167176. https://doi.org/10.1093/bfgp/els007

Etezadi-Amoli, J., and Farhoomand, A. F., 1996. A structural model of end user computing satisfaction and user performance. Information \& Management, 30, pp. 65 - 73. https://doi.org/10.1016/0378-7206(95)00052-6

Ferratt, T. W., Agarwal, R., Brown, C. V., and Moore, J. E., 2005. IT human resource management configurations and IT turnover: Theoretical synthesis and empirical analysis. Information systems research, 16(3), pp. 237-255. https://doi.org/10.1287/isre.1050.0057

Fornell, C., and Larcker, D. F., 1981. Structural equation models with unobservable variables and measurement error: Algebra and statistics. Journal of marketing research, pp. 382388. https://doi.org/10.1177/002224378101800313

Furneaux, B., 2012. Task - Technology Fit Theory: A survey and synopsis of the literature. In: Y. K., Dwivedi, M. R., Wade and S. L., Schneberger, eds. 2012. Information systems theory: Explaining and predicting our digital society (Vol 1). New York: Springer, pp. 87 $-106$.

Goodhue, D. L., 1995. Understanding user evaluations of information systems. Management Science, 41(12), pp. 1827-1844. https://doi.org/10.1287/mnsc.41.12.1827

Goodhue, D. L., and Thompson, R. L., 1995. Task-technology fit and individual performance. Management Information Systems Quarterly, 19(2), pp. 213-236. https://doi.org/10.2307/249689

Goodhue, D., Littlefield, R., and Straub, D. W., 1997. The measurement of the impacts of the IIC on the end-users: The survey. Journal of the Association for Information Science and Technology, 48(5), pp. 454-465.

Igbaria, M., and Tan, M., 1997. The consequences of information technology acceptance on subsequent individual performance. Information \& management, 32(3), pp. 113-121. https://doi.org/10.1016/S0378-7206(97)00006-2

Jiang, J. J., G. Klein, and Saunders, C., 2012. Discrepancy theory models of satisfaction in IS research. In: Y. K., Dwivedi, M. R., Wade and S. L., Schneberger, eds. 2012. Information systems theory: Explaining and predicting our digital society (Vol 1). New York: Springer, pp. 355 - 381. https://doi.org/10.1007/978-1-4419-6108-2 18

Judge, T. A., Thoresen, C. J., Bono, J. E., and Patton, G. K., 2001. The job satisfaction-job performance relationship: A qualitative and quantitative review. Psychological Bulletin, 127(3), pp. 376 - 407. https://doi.org/10.1037/0033-2909.127.3.376

Hair Jr, J. F., Hult, G. T. M., Ringle, C., and Sarstedt, M., 2016. A primer on partial least squares structural equation modeling (PLS-SEM). Thousand Oaks, CA: Sage Publications.

Henseler, J., Ringle, C. M., and Sarstedt, M., 2015. A new criterion for assessing discriminant validity in variance-based structural equation modeling. Journal of the Academy of Marketing Science, 43(1), pp. 115-135. https://doi.org/10.1007/s11747-014-0403-8

Kanellou, A., and Spathis, C., 2013. Accounting benefits and satisfaction in an ERP environment. International Journal of Accounting Information Systems, 14, pp. 209-234. https://doi.org/10.1016/j.accinf.2012.12.002

Kock, N., 2015. Common method bias in PLS-SEM: A full collinearity assessment approach. International Journal of e-Collaboration (IJeC), 11(4), pp. 1-10.

Kositanurit, B., Ngwenyama, O., and Osei-Bryson, K. M., 2006. An exploration of factors that impact individual performance in an ERP environment: An analysis using multiple analytical techniques. European Journal of Information Systems, 15(6), pp. 556-568. https://doi.org/10.1057/palgrave.ejis.3000654

Lindell, M. K., and Whitney, D. J., 2001. Accounting for common method variance in crosssectional research designs. Journal of applied psychology, 86(1), pp. 114-121. https://doi.org/10.1037/0021-9010.86.1.114 
Huy et al. / Eurasian Journal of Economics and Finance, 7(1), 2019, 48-61

Markus, M. L., and Tanis, C., 2000. The enterprise systems experience-from adoption to success. Framing the domains of IT research: Glimpsing the future through the past, 173, pp. 207-173.

Michalos, A. C., 1985. Multiple discrepancies theory (MDT). Social Indicators Research, 16(4), pp. 347-413. https://doi.org/10.1007/BF00333288

Morris, M. G., and Venkatesh, V., 2010. Job characteristics and job satisfaction: Understanding the role of enterprise resource planning system implementation. MIS Quarterly, 34(1), pp. 134 - 161. https://doi.org/10.2307/20721418

Norzaidi, M. D., Chong, S. C., Murali, R., and Salwani, M. I., 2009. Towards a holistic model in investigating the effects of intranet usage on managerial performance: A study on Malaysian port industry. Maritime Policy and Management, 36(3), pp. 269-289. https://doi.org/10.1080/03088830902861235

Park, J. H., Suh, H. J., and Yang, H. D., 2007. Perceived absorptive capacity of individual users in performance of Enterprise Resource Planning (ERP) usage: The case for Korean firms. Information \& Management, 44(3), pp. 300-312. https://doi.org/10.1016/j.im.2007.02.001

Petter, S., DeLone, W., and McLean, E. R., 2013. Information systems success: The quest for the independent variables. Journal of Management Information Systems, 29(4), pp. 762. https://doi.org/10.2753/MIS0742-1222290401

Plaza, M., and Rohlf, K., 2008. Learning and performance in ERP implementation projects: A learning-curve model for analyzing and managing consulting costs. International Journal of Production Economics, 115(1), pp. 72-85. https://doi.org/10.1016/j.ijpe.2008.05.005

Podsakoff, P. M. and Organ, D. W., 1986. Self-reports in organizational research: Problems and prospects. Journal of Management, 12(4), pp. 531 - 544. https://doi.org/10.1177/014920638601200408

Podsakoff, P. M., MacKenzie, S. B., Lee, J. Y., and Podsakoff, N. P., 2003. Common method biases in behavioral research: a critical review of the literature and recommended remedies. J Appl Psychol, 88(5), pp. 879-903. https://doi.org/10.1037/00219010.88.5.879

Porter, L. W., and Lawler, E. E., 1968. Managerial attitudes and performance. Homewood, III: R. D. Irwin.

Rajan, C. A. and Baral, R., 2015. Adoption of ERP system: An empirical study of factors influencing the usage of ERP and its impact on end user. IIMB Management Review, 27, 105- 117. https://doi.org/10.1016/.iimb.2015.04.008

Ruppel, C. P., and Harrington, S. J., 1995. Telework: An innovation where nobody is getting on the bandwagon? ACM SIGMIS Database: the DATABASE for Advances in Information Systems, 26(2-3), pp. 87-104.

Staples, D. S., and Seddon, P., 2004. Testing the technology-to-performance chain model. Journal of Organizational and End User Computing (JOEUC), 16(4), pp. 17-36. https://doi.org/10.4018/joeuc.2004100102

Sykes, T. A., 2015. Support structures and their impacts on employee outcomes: A longitudinal field study of an enterprise system implementation. MIS Quarterly, 39(2), pp. $473-495$. https://doi.org/10.25300/MISQ/2015/39.2.09

Sykes, T. A., Venkatesh, V., and Johnson, J. L., 2014. Enterprise system implementation and employee job performance: Understanding the role of advice networks. MIS Quarterly, 30(1), pp. 51 - 72. https://doi.org/10.25300/MISQ/2014/38.1.03

Teo, T. S., and Bing, M., 2008. Knowledge portals in Chinese consulting firms: A tasktechnology fit perspective. European Journal of Information Systems, 17(6), pp. 557574. https://doi.org/10.1057/ejis.2008.41

Volkoff, O., Strong, D. M., and Elmes, M. B., 2007. Technological embeddedness and organizational change. Organization Science, 18(5), pp. 832-848. https://doi.org/10.1287/orsc. 1070.0288

Wei, C. and Wang, M. J., 2004. A comprehensive framework for selecting an ERP system. International Journal of Project Management, 22, pp. 161-169. https://doi.org/10.1016/S0263-7863(02)00064-9 
Huy et al. / Eurasian Journal of Economics and Finance, 7(1), 2019, 48-61

Wongpinunwatana, N., Ferguson, C., and Bowen, P., 2000. An experimental investigation of the effects of artificial intelligence systems on the training of novice auditors. Managerial Auditing Journal, 15(6), pp. 306-318. https://doi.org/10.1108/02686900010344511

Zigurs, I., and Buckland, B. K., 1998. A theory of task/technology fit and group support systems effectiveness. MIS Quarterly, 22(3), pp. 313-334. https://doi.org/10.2307/249668 
Appendix. Cross loading

\begin{tabular}{|l|r|r|r|r|r|r|r|}
\hline & CURR & EOU & MEAN & PER & PU & RDAT & RDET \\
\hline CURR & $\mathbf{1 . 0 0 0}$ & 0.390 & 0.387 & 0.351 & 0.314 & 0.143 & 0.618 \\
\hline EOU1 & 0.358 & $\mathbf{0 . 9 5 3}$ & 0.480 & 0.633 & 0.503 & 0.311 & 0.328 \\
\hline EOU2 & 0.386 & $\mathbf{0 . 9 5 7}$ & 0.542 & 0.732 & 0.595 & 0.264 & 0.387 \\
\hline MEAN & 0.387 & 0.535 & $\mathbf{1 . 0 0 0}$ & 0.634 & 0.532 & 0.147 & 0.519 \\
\hline PER1 & 0.290 & 0.694 & 0.626 & $\mathbf{0 . 9 6 6}$ & 0.721 & 0.110 & 0.418 \\
\hline PER2 & 0.386 & 0.692 & 0.601 & $\mathbf{0 . 9 7 0}$ & 0.762 & 0.103 & 0.531 \\
\hline PU1 & 0.251 & 0.513 & 0.467 & 0.723 & $\mathbf{0 . 8 8 4}$ & 0.044 & 0.379 \\
\hline PU2 & 0.239 & 0.420 & 0.442 & 0.633 & $\mathbf{0 . 8 5 5}$ & -0.060 & 0.422 \\
\hline PU3 & 0.318 & 0.469 & 0.358 & 0.633 & $\mathbf{0 . 8 5 4}$ & 0.039 & 0.356 \\
\hline PU4 & 0.292 & 0.485 & 0.469 & 0.679 & $\mathbf{0 . 9 1 3}$ & 0.013 & 0.382 \\
\hline PU5 & 0.250 & 0.535 & 0.543 & 0.687 & $\mathbf{0 . 9 0 0}$ & 0.030 & 0.342 \\
\hline PU6 & 0.302 & 0.593 & 0.506 & 0.669 & $\mathbf{0 . 8 4 9}$ & 0.064 & 0.323 \\
\hline RDAT & 0.143 & 0.301 & 0.147 & 0.110 & 0.026 & $\mathbf{1 . 0 0 0}$ & 0.125 \\
\hline RDET & 0.618 & 0.375 & 0.519 & 0.492 & 0.418 & 0.125 & $\mathbf{1 . 0 0 0}$ \\
\hline
\end{tabular}

